\title{
Modeling the competitive environment of the entrepreneurship cluster
}

\author{
Viktoriya Sevka ${ }^{1,}{ }^{*}$, Dmitry Nekhaychuk $^{2}$, Viktoriia Sihua ${ }^{1}$, and Andrei Shevchuk ${ }^{2}$ \\ ${ }^{1}$ Academy of Civil Engineering and Architecture, Derzhavina str., 2, 286123, Donetsk, Ukraine \\ ${ }^{2}$ Sevastopol Branch of Plekhanov Russian University of Economics, Vakulenchuka Str., 29-4, \\ Sevastopol, Russia
}

\begin{abstract}
The paper aims to verify the hypothesis about cooperation expediency of different in scale and similar in activity entities in the form of the entrepreneurship cluster for ensuring energy needs of the region. The integral coefficients of economic development of the innovative component of industrial enterprises on energy activity, the financial component of communal enterprises for heat supply, the readiness of small enterprises operating in the energy industry for innovative transformations has been analysed. Modeling of the competitive environment of the entrepreneurship cluster allowed to reveal logical interrelation between the level of technological changes in industry and technological capabilities of communal and small enterprises and to define their sectoral positions.
\end{abstract}

\section{Introduction}

The intensification of innovation activities against the background of transformations in the natural, resource, social, economic, cultural and technical spheres requires the adaptation of new organizational forms of activity. Intensification of globalization phenomena, energy independence and redistribution of energy resources for industrial, housing and communal consumption require research of the current condition of the competitive environment of industrial, communal and small enterprises and the possibility of their work as part of the entrepreneurial cluster.

Research of problems in regional and spatial development, resource planning, evaluation of financial and innovative components, diagnostics of the enterprise innovation potential, cluster analysis, innovative activity, strategic planning and management of innovative development in a highly competitive environment in the context of regionalization and globalization are devoted to the work of national and foreign scientists. However, the theoretical basis and practical effectiveness evaluation of the cooperation of different scale enterprises that work to supply power to regional consumers, taking into account factors of innovation remain relevant.

\footnotetext{
* Corresponding author: v.g.sevka@donnasa.ru
} 


\section{Theoretical, Informational and Empirical, and Methodological Grounds of the Research}

The aggravation of economic relations in the communal sector, the increase in social tensions and difficulties in adapting foreign experience force enterprises to use innovative ways of cooperation with business structures, financial institutions and organizations that respond quickly and effectively solve complex problems in the industry. Increasing the number of partnerships, innovative approaches, programs, initiatives and projects that contribute to the social, economic and environmental well-being of large industrial cities should be the task of the state, local authorities, heads of communal enterprises.

Increased attention to the problem of the interaction of globalization and regionalization causes the need for a specific formal or regional-spatial approach to improve the conditions of entrepreneurship (P.V. Shukanov, 2012).

Experts note that it is advisable to use a variety of criteria to assess the impact of globalization and regionalization on the development of both individual and different ethno-cultural groups of the population while studying global socio-geographical processes of transformation of the world economy. Modern research suggests that this thesis can be applied to economic systems (enterprises), as well as to the totality of business entities (cluster and adjacent infrastructure) to identify the reasons for the decrease in work efficiency and to identify promising ways to solve problems (V.S. Bochko, 2015).

Management experience of recent years clearly shows that the need for cooperation on the part of communal companies is constantly growing, because joining to the cluster means free access to experts, information and investment.

The cluster form implies the creation of such an organizational and economic mechanism of strategic priorities of innovative development of territories, which is aimed at restoring financial stability, strengthening the technical sphere and achieving competitive advantages of communal enterprises in the territories where large business structures presents, taking into account the synergetic effect. V.P. Solovyov notes that «the points of growth» of innovation clusters are small enterprises. The beginning of their development is given by enterprises that are already successfully operating in the market (A.A. Melikhov, 2014).

Research of transformation phenomena in the innovation environment and the process of evolution of cluster formations allows to determine the essence of the entrepreneurial cluster as an effective mechanism of market self-regulation for the implementation of entrepreneurial innovations to improve the competitiveness of the economy sectors within the framework of the chosen strategy of innovative development. The decentralization of management decisions as the condition for the emergence of an entrepreneurial cluster, and the attraction to the priority sectors as a point of growth were identified as the main features of the entrepreneurial cluster. Entrepreneurial clustering is developed on the basis of the business cluster technology.

Multidimensional cluster analysis and selective indicators of economic systems development point to the important role of the entrepreneurial cluster in the energy industry. Entrepreneurial cluster in the power industry is a united network of entities that product, supply of power services and provide the accompanying services. It is an economic system aimed to obtain the economic benefits and to achieve qualitative and quantitative indicators of the socially-oriented strategy of the state. At the same time, small entrepreneurship makes the role of integrating the conditions when participants enter into entrepreneurial cluster. Small entrepreneurship is also carry out the methods of direct and indirect state regulation while economic system is organized.

In order to assess the level of innovative development of industrial, communal and small enterprises in the entrepreneurial cluster, it is proposed to apply the methodology of 
selecting the sector. It determines the industrial technological and organizational features of the development of innovation. As a result of the systematization of the analytical control points of the level of innovation activity, we will build the logic of the research according to the presented scheme (Figure 1).

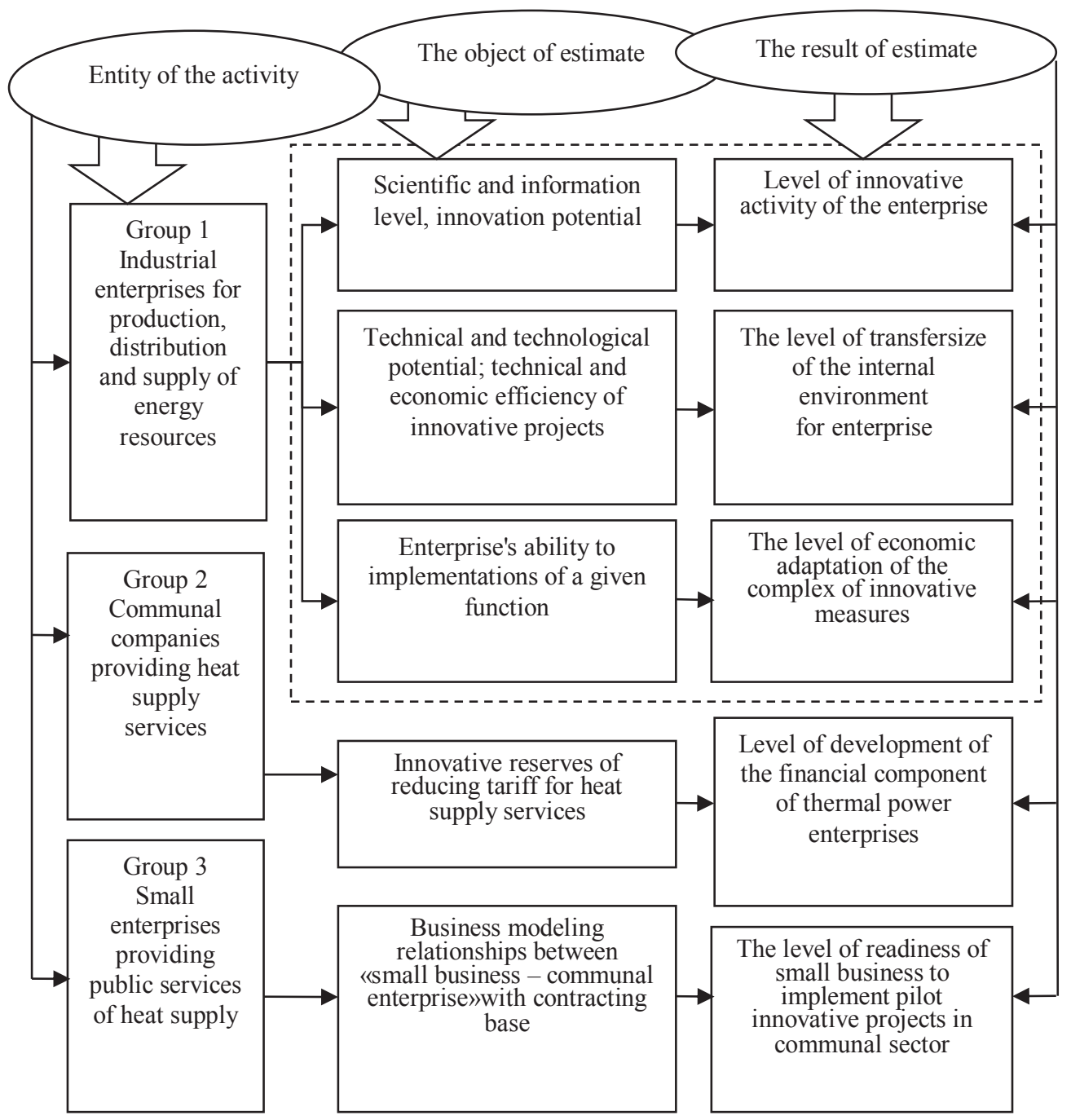

Fig. 1. Directions of Complex Assessment of Elements of Innovative Potential and Efficiency of Innovative Activity for the Enterprises in Entrepreneurial Cluster.

The first stage of the methodology involves the evaluation of innovative activities of industrial enterprises (Moskalenko V.P., 2009; Tishchenko O.M., 2008; Statistical Yearbook, 2014) for the production, distribution and supply of energy resources in following areas:

1) The level of activity of innovative activity of the enterprise, which characterizes the organizational, social, technical and financial components $R_{i a}$ (innovative activity, the development of technosphere, personnel training, the introduction of new (low-waste, resource-saving, waste-free) technological processes, the cost of innovation activities and the development of technosphere, the cost of mastering the production of innovative 
products, the introduction of innovative processes, organizational and marketing innovations);

2) The level of innovation transfersize at the enterprise, which characterizes the financial component $R_{t}$ (costs for external and internal research, acquisition and transfer of new technologies);

3) Economic adaptation of innovative measures at the enterprise, which characterizes commercialization and financial component $R_{a}$ (market introduction of innovations, implementation of innovative products, financing innovation activities at their own expense, state, local budgets and extra-budgetary funds, domestic and foreign investors, loans and others).

The results of the estimate of the system of special indicators of innovation activity of the first group of contractors, which may be part of the entrepreneurial cluster $-R_{i}$, are presented in Table 1.

Table 1. Rates of Innovative Development of Enterprises on Production, Distribution and Supply of Energy Resources (Prepared by the authors on the basis of Scientific and Innovative Activity in Ukraine).

\begin{tabular}{|c|c|c|c|c|c|c|c|c|}
\hline \multirow{2}{*}{ } & \multicolumn{4}{|c|}{ Rates } & \multicolumn{4}{|c|}{ Growth Index } \\
\hline & $R_{i a}$ & $R_{t}$ & $R_{a}$ & $R_{i}$ & $R_{i a}$ & $R_{t}$ & $R_{a}$ & $R_{i}$ \\
\hline $\mathrm{P} 1$ & $\begin{array}{c}0,026 \\
\text { min }\end{array}$ & $\begin{array}{c}0,002 \\
\text { min }\end{array}$ & 0,091 & $\begin{array}{c}0,040 \\
\text { min }\end{array}$ & $\mathrm{X}$ & $\mathrm{X}$ & $\mathrm{X}$ & $\mathrm{X}$ \\
\hline $\mathrm{P} 2$ & 0,028 & 0,003 & 0,103 & 0,045 & 1,07 & 1,17 & 1,13 & 1,12 \\
\hline P3 & 0,038 & 0,005 & $\begin{array}{c}0,091 \\
\text { min }\end{array}$ & 0,045 & 1,39 & 1,64 & 0,88 & 1,00 \\
\hline P4 & $\begin{array}{c}0,128 \\
\max \end{array}$ & 0,152 & 0,242 & 0,174 & $\begin{array}{l}3,34 \\
\max \end{array}$ & $\begin{array}{c}33,00 \\
\max \end{array}$ & $\begin{array}{l}2,66 \\
\max \end{array}$ & $\begin{array}{l}3,90 \\
\max \end{array}$ \\
\hline P5 & 0,106 & $\begin{array}{c}0,239 \\
\max \\
\end{array}$ & $\begin{array}{c}0,253 \\
\max \end{array}$ & $\begin{array}{c}0,199 \\
\max \\
\end{array}$ & 0,82 & 1,57 & 1,05 & 1,14 \\
\hline P6 & 0,049 & 0,080 & 0,126 & 0,085 & $\begin{array}{c}0,46 \\
\text { min }\end{array}$ & $\begin{array}{c}0,34 \\
\mathrm{~min}\end{array}$ & $\begin{array}{l}0,50 \\
\text { min }\end{array}$ & $\begin{array}{l}0,43 \\
\mathrm{~min}\end{array}$ \\
\hline $\mathrm{P} 7$ & 0,070 & 0,096 & 0,163 & 0,110 & 1,43 & 1,20 & 1,29 & 1,29 \\
\hline $\bar{x}$ & 0,064 & 0,082 & 0,153 & 0,010 & 1,22 & 5,56 & 1,07 & 1,27 \\
\hline
\end{tabular}

The dynamics of the innovative component of the economic development of industrial enterprises for the production, distribution and supply of energy resources is presented in Figure 2. 


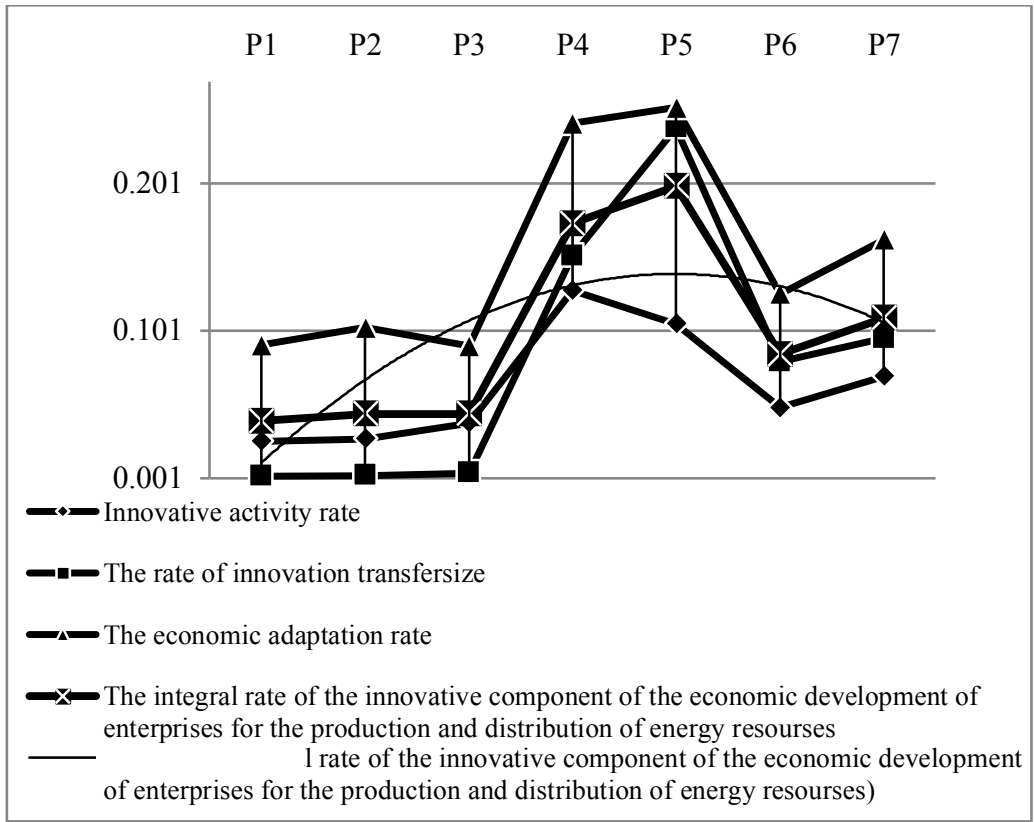

Fig. 2. Dynamics of the Innovative Component of the Economic Development of Industrial Enterprises for Production, Distribution and Supply of Energy Resources for the Research Period.

Guided by the methodology of diagnostics of innovative potential of the industrial enterprise (Shipulina Yu.S., 2008), the law of proportional development, the principle of balance and proportionality of production placement in the region, signs of complex proportional development of types and branches of activity (Vasilenko V.M., 2014) we defined sufficiency levels of innovative development of the enterprises for production, distribution and supply of energy resources (Table 2).

Table 2. Assessment of the Adequacy of Economic Potential for the Implementation of Projects of Innovative Development of Industrial Enterprises for the Production, Distribution and Supply of Energy Resources (Prepared by the authors on the basis of the references (Shipulina Yu.S., 2008; Vasilenko V.M., 2014).

\begin{tabular}{|c|c|c|c|}
\hline Value $_{\min }$ & Indicator & Value $_{\operatorname{mx}}$ & Meaning \\
\hline 0.23 & $\leq$ Hgen. $\leq$ & 0.25 & Absolute sufficiency \\
\hline 0.17 & $\leq$ Hgen. $\leq$ & 0.23 & Normal sufficiency \\
\hline 0.11 & $\leq$ Hgen. $\leq$ & 0.17 & Unstable state \\
\hline 0.05 & $\leq$ Hgen. $\leq$ & 0.11 & Critical condition \\
\hline 0.00 & $\leq$ Hgen. $\leq$ & 0.05 & Crisis condition \\
\hline
\end{tabular}

The value of the integral coefficient of the innovative component of the economic development of industrial enterprises for the production, distribution and supply of energy resources indicates the transformation phenomena from the crisis to the unstable state of the internal environment of the enterprise. In particular, this trend was due to growth ratio of transversal and adaptation. The rate of innovation activity decreased slightly. During research period, energy companies failed to reach a mark that would characterize the current state of innovative development as normal.

The polynomial dynamics curve of the integral rate of the innovative component of the economic development in industrial enterprises for the production and distribution of energy resources indicates has the tendency to increase the innovative activity of large 
energy enterprises and to the gradual improvement of the innovation macro-climate. Based on the results of the estimate of this indicator, we can make the conclusion about the level of technological changes in the industry.

The next step will be the analyzes the main financial results of activities that affect the tariff policy of heat supply enterprises. This will determine the readiness of the communal sector to innovative transformations and will be a stimulating motive for attracting small entrepreneurship on the basis of innovative management.

There is noted the existence of a relationship between the level of innovative development potential of the enterprise and financial resources for the implementation of innovative development strategy (V.M. Vasilenko, 2014; A.A. Melikhov, 2014; L.S. Zakharkina, 2011; S. Zahra, R. Sisodia, B. Matherne, 1999) in substantiating the aspects of strategic planning in the management of innovative development of industrial enterprises. Therefore, we define the integral rate that characterizes the readiness for innovative transformations, provided that financial development is sufficient (A.A. Trifilova, 2017).

Analysis of the financial component involves the evaluation of the final results of the communal enterprises, which give an idea of the optimal ratio between income and expenditure, updating the problem of optimizing the structure of tariffs.

There was defined the tendency to increase the costs of heat supply, that reflects the regional situation regarding the rise in price of services by $30.6 \%$ in some industrial cities such as Gorlovka, Donetsk, Kramatorsk, Makeyevka, Mariupol. This fact is contradiction of social policy. In addition, the growth of the material component of the tariffs led to the deterioration of the financial and technical condition of the communal heating enterprises of Donetsk region. Tariffs did not cover the actual cost of heat supply services, and the level of compensation for the price of natural gas was $79.5 \%$, electricity $-51.6 \%$ (Figure 3).

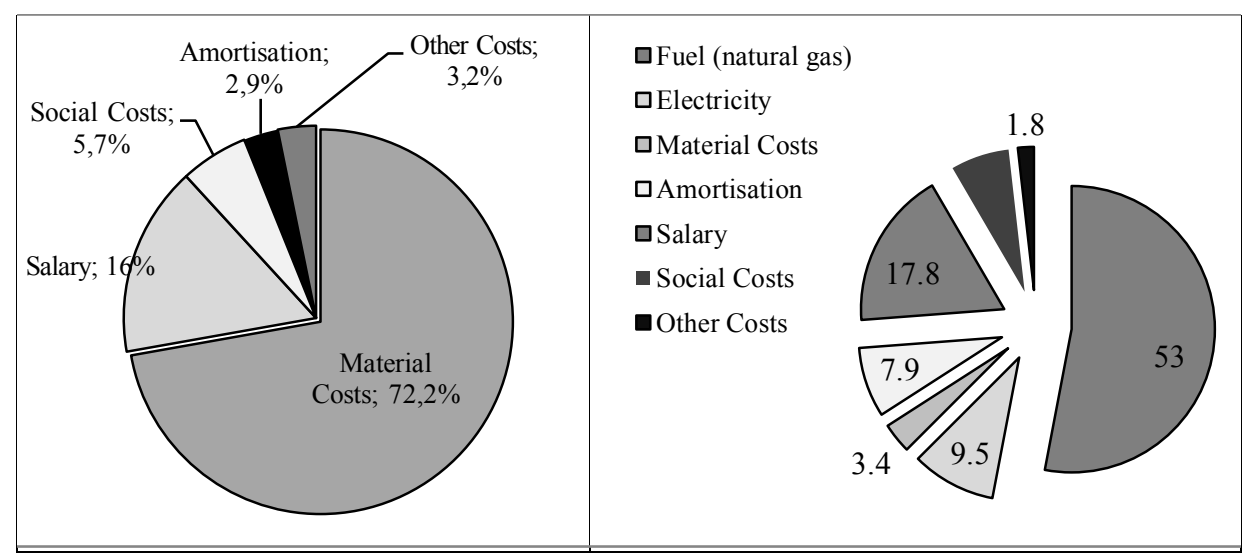

Fig. 3. Structure of Tariffs of the Communal Enterprises of Heat Power Engineering in Donetsk Region (on the Left) in 2011 (P4) and Across the Country (on the Right) in 2014 (P6).

The high material intensity of heat supply services in Donetsk region is evidenced by the index of operating costs per 1 mon.unit net income from services, which increased from 1.34 to $1.58(17.9 \%)$ (Figure4). 


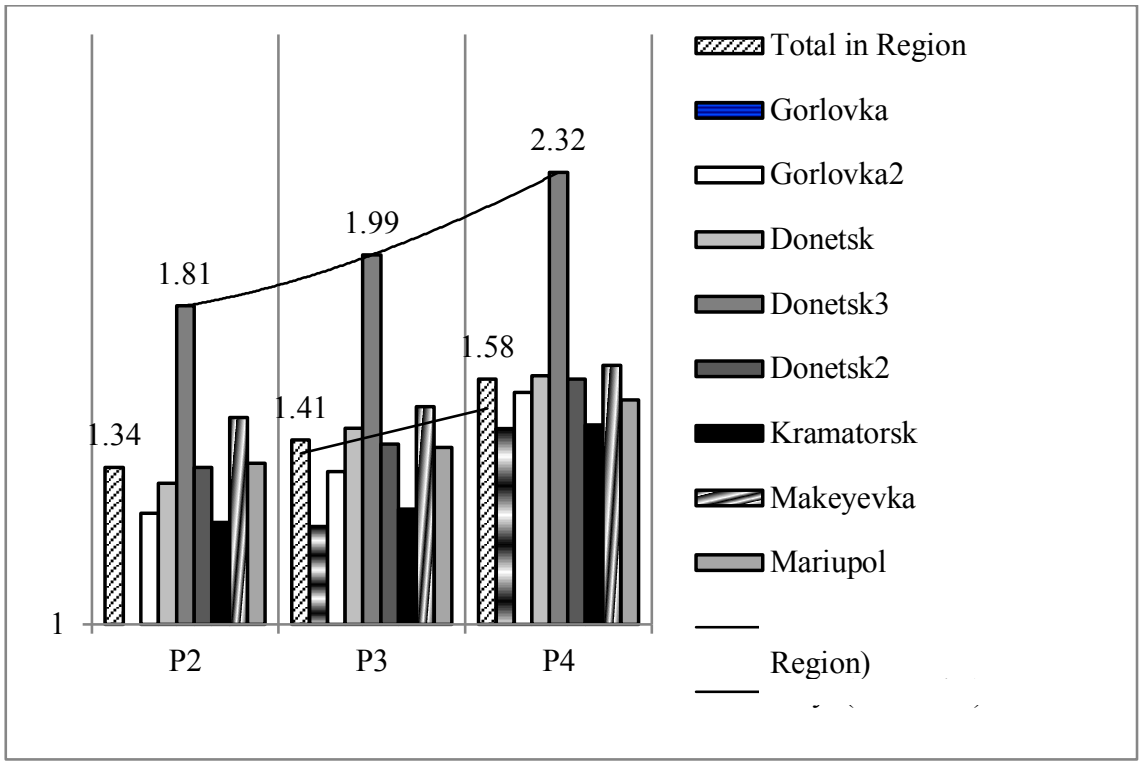

Fig. 4. Dynamics of Operating Costs per 1 mon.unit of the net Income from Realization of Heat Supply Services by the Communal Enterprises in Some Industrial Cities of Donetsk region.

There are presented the analytical assessment of the level and dynamics of operating and material costs of heat supply enterprises (Table 3).

Table 3. Analysis of Material Consumption and Material Efficiency of Thermal Energy of Heat Supply Enterprises (Prepared by the authors on the basis of the data provided by Donetsk Regional State Administration and Head Department of Housing and Communal Services of Donetsk Region, communal enterprises' reports).

\begin{tabular}{|l|c|c|c|c|c|c|}
\hline \multicolumn{1}{|c|}{ Indicator } & \multicolumn{5}{|c|}{ Period } & \multicolumn{3}{c|}{ Growth Rate. \% } \\
\cline { 2 - 7 } & P2 & P3 & P4 & P3/P2 & P4/P3 & P4/P2 \\
\hline $\begin{array}{l}\text { 1. Thermal energy. } \\
\text { thous. GCal }\end{array}$ & 6812.7 & 7265.9 & 7690.8 & 6.65 & 5.85 & 12.89 \\
\hline $\begin{array}{l}\text { 2. Cost (tariff) (C). } \\
\text { mon.units / GCal }\end{array}$ & 320.6 & 358.7 & 418.8 & 11.88 & 16.75 & 30.63 \\
\hline $\begin{array}{l}\text { 3. Net income from } \\
\text { services' sales. thous. } \\
\text { mon.units }\end{array}$ & 1632794.8 & 1848850.5 & $\begin{array}{c}2043031 \\
.8\end{array}$ & 13.23 & 10.50 & 25.12 \\
\hline $\begin{array}{l}\text { 4. Operating costs for } \\
\text { 1 mon.unitof net } \\
\text { income. mon.units } \\
\text { (line 1 * line 2 : line } \\
\text { 3) }\end{array}$ & 1.34 & 1.41 & 1.58 & 5.22 & 12.06 & 17.91 \\
\hline $\begin{array}{l}\text { 5. Tariff revenue (C). } \\
\text { thous. mon.units (line } \\
\text { 1 *line 2) }\end{array}$ & 2184151.6 & 2606278.3 & 3220907 & 19.33 & 23.58 & 47.47 \\
\hline $\begin{array}{l}\text { 6. Material costs for 1 } \\
\text { unit. mon.units / GCal }\end{array}$ & 223.2 & 246.4 & 302.5 & 10.39 & 22.77 & 35.53 \\
\hline $\begin{array}{l}\text { 7. General material } \\
\text { costs. thous. mon.units } \\
\text { (line 1 * line 6) }\end{array}$ & 1520594.6 & 1790317.8 & 2326467 & 17.74 & 29.95 & 53.00 \\
\hline $\begin{array}{l}\text { 8. The consumption of } \\
\text { thermal energy (C)(line } \\
\text { 7: line 5) }\end{array}$ & 0.70 & 0.69 & 0.72 & -1.43 & 4.35 & 2.86 \\
\hline
\end{tabular}




\begin{tabular}{|l|c|c|c|c|c|c|}
\hline $\begin{array}{l}\text { 9. Material efficiency } \\
\text { (C)(line 5: line 7) }\end{array}$ & 1.44 & 1.46 & 1.38 & 1.39 & -5.48 & -4.17 \\
\hline $\begin{array}{l}10 . \quad \text { The level of } \\
\text { compensation rate } \\
\text { (average). } \\
\text { including: }\end{array}$ & 93.77 & - & 90.60 & - & - & -3.38 \\
\hline $\begin{array}{c}\text { for the population } \\
\text { for non-industrial } \\
\text { consumer groups }\end{array}$ & 59.3 & 63.5 & 51.7 & 7.08 & -18.58 & -12.8 \\
\hline $\begin{array}{l}\text { for industrial } \\
\text { consumer groups }\end{array}$ & 123.2 & - & 133.9 & - & - & 8.69 \\
\hline $\begin{array}{l}11 . \text { Impact of changes } \\
\text { in material costs } \\
\Delta Q^{m} \text {. } \\
\text { mon.units / GCal }\end{array}$ & - & 33.41 & 81.91 & - & - & 145.2 \\
\hline $\begin{array}{l}12 . \text { The impact of } \\
\text { changes in material } \\
\text { efficiency } \Delta Q_{f}^{m} \text {. } \\
\text { mon.units / GCal }\end{array}$ & - & 4.93 & 18.15 & - & - & 268.2 \\
\hline
\end{tabular}

The results of the assessment show that for 1 mon.unit of giga-calorie's production of heat accounts for 0.7 mon.unit cost of material costs in average. The results of factor analysis indicate that the increase in material costs leads to an increase in tariff income. As a result of changes in material efficiency tariff income is also increased.

The next one we are going to determine the level of development of the financial component of communal enterprises of thermal power, taking into account the analysis of material consumption and material efficiency of thermal energy (Table 4).

Table 4. Assessment of Parameters of Financial and Economic Growth for the Communal Enterprises of Heat Supply (Prepared by the authors on the basis of Table 3).

\begin{tabular}{|l|c|c|c|}
\hline \multicolumn{1}{|c|}{ Indicator } & \multicolumn{3}{|c|}{ Period } \\
\cline { 2 - 4 } & P2 & P3 & P4 \\
\hline $\begin{array}{l}\text { 1. Relation coefficient between the net income from } \\
\text { services' sales and the costs of ordinary activities in the } \\
\text { provision of services }\end{array}$ & 0.72 & 0.69 & 0.61 \\
\hline $\begin{array}{l}\text { 2. Relation coefficient between operating income and } \\
\text { operating expenses }\end{array}$ & 0.23 & 0.09 & 0.19 \\
\hline $\begin{array}{l}\text { 3. Relation coefficient between financial income and } \\
\text { expenses of ordinary activities }\end{array}$ & 0.026 & 0.018 & 0.021 \\
\hline $\begin{array}{l}\text { 4. Relation coefficient between the financial result (loss) } \\
\text { and the cost of the ordinary course of business }\end{array}$ & -0.03 & -0.21 & -0.19 \\
\hline $\begin{array}{l}\text { 5. Relation coefficient between the volume of paid } \\
\text { services and the costs of ordinary activities }\end{array}$ & 0.86 & 0.75 & 0.72 \\
\hline $\begin{array}{l}\text { 6. Relation coefficient between the cost of maintaining } \\
\text { social facilities and operating costs }\end{array}$ & 0.0012 & 0.00082 & 0.0007 \\
\hline $\begin{array}{l}\text { 7. Profitability of services (ratio of financial results from } \\
\text { ordinary activities (profit) to costs of ordinary activities) }\end{array}$ & 0.006 & 0.00016 & 0.00035 \\
\hline 8. Innovative potential of employees & 0.20 & 0.21 & 0.26 \\
\hline $\begin{array}{l}\text { 9. Relation coefficient between depreciation costs and } \\
\text { normal business expenses }\end{array}$ & 0.03 & 0.03 & 0.028 \\
\hline $\begin{array}{l}\text { 10. Integral coefficient of stability of financial and } \\
\text { economic growth IC feg (taking into account material } \\
\text { intensity and heat output) }\end{array}$ & 0.38 & 0.34 & 0.34 \\
\hline
\end{tabular}


Table 4 shows that the integral coefficient of stability of financial and economic growth of the enterprises of heat supply of the Donetsk region was at the level of 0.35 .

At the third stage, we will determine the level of readiness of small enterprises for working in the sphere of industry and services and for innovative transformations by the assessment the coefficient of innovation activity $C S I_{i a}$. The results of the survey of innovation activities of small enterprises working in the field of industry and services, revealed the following levels of innovation activity (Table 5).

Table 5. Initial Data for Assessment of the Integral Index of Readiness of Small Enterprises for Innovation Conductor in Communal Sector (Prepared by the authors on the basis of Official data of Donetsk Regional State Administration and Head Department of Housing and Communal Services of Donetsk Region).

\begin{tabular}{|l|c|c|}
\hline \multicolumn{1}{|c|}{ Indicator } & $\begin{array}{c}\text { Characteristics of innovative activity of small enterprises } \\
\text { during the research period }\end{array}$ \\
\hline $\begin{array}{c}\text { Innovation } \\
\text { Activity }\end{array}$ & With Technological Innovations & $\begin{array}{c}\text { With Organizational } \\
\text { Innovation }\end{array}$ \\
\hline In total & 1562 (surveyed 24657) & 2608 \\
\hline$C S I_{i a}$ & Innovative 0.37 (surveyed 0.06) & $\begin{array}{c}\text { Innovative } 0.63 \\
\text { (surveyed } 0.11 \text { ) }\end{array}$ \\
\hline Industry & 885 (surveyed 10430) & 983 \\
\hline$C S I_{i a}$ & Innovative 0.47 (surveyed 0.08) & $\begin{array}{c}\text { Innovative } 0.53 \\
\text { (surveyed 0.09) }\end{array}$ \\
\hline Services & 677 (surveyed 14227) & 1625 \\
\hline$C S I_{i a}$ & Innovative 0.29 (surveyed 0.05) & $\begin{array}{c}\text { Innovative } 0.71 \\
\text { (surveyed } 0.11 \text { ) }\end{array}$ \\
\hline
\end{tabular}

Thus, small enterprises with organizational innovation have a higher rate of innovation than enterprises with technological innovation, especially in the service sector. Generation and consumption of energy resources in a rapidly growing competitive environment requires rapid response of energy enterprises to changes in the external environment to adapt effective innovation strategies. The most effective are economic competitive strategies based on competitive advantages and combining marketing, financial and technological resources.

Foreign experience in the organization of interaction between technological and competitive strategies (S. Zahra, R. Sisodia, B. Matherne, 1999; P. L. Chang, Y. C. Chen, 1994 ) indicates the creation of eight strategic zones embodied in the region:

1) Low-tech environment (competition arises due to high-tech changes instead of incremental innovations);

2) Technologically «sleeping» environment (managed by competitor-leader and apply new (improved) products and technologies);

3) Environment with high speed of technological changes in the industry, low technological heterogeneity among key players and weak technological capabilities of the enterprise (emphasis on competitive advantages in the form of new technologies);

4) Increasing industrial environment with competitors differentiated by technological advantages. At the same time, low-tech competitors should have convincing data to deliver competitive competence to the market;

5) Environment is close to the second situation, but the difference lies in the ownership of the enterprise significant technological innovations in the industry, causing small technological changes;

6) Environment that continues the fifth situation (the company may face additional technological competitors in this low-technology market);

7) Environment in which each enterprise is a technologically capable entity; 
8) Environment in which strategic options are limited and enterprises unable to innovate at a high level take the position of followers.

\section{Results}

Based on the results of a comprehensive assessment of the efficiency of innovative activity of energy companies in the region, economic and mathematical models are built taking into account the technological and organizational characteristics of the participants of the innovation and industry cluster (Table 6).

Table 6. Source Data for Modeling (Prepared by the authors on the basis of Table 5).

\begin{tabular}{|c|c|c|c|}
\hline $\begin{array}{c}\text { Technological Capabilities of } \\
\text { Enterprises in the Region Depending } \\
\text { on the Level of Technological Changes } \\
\text { in the Industry }\end{array}$ & $\begin{array}{c}\text { Organizational Capabilities of } \\
\text { Enterprises in the Region Depending } \\
\text { on the Level of Technological Changes } \\
\text { in the Industry }\end{array}$ \\
\hline Value X & Value Y & Value X & Value Y \\
\hline 0.611 & 0.35 & 0.611 & 0.35 \\
\hline 0.611 & 0.47 & 0.611 & 0.53 \\
\hline 0.611 & 0.29 & 0.611 & 0.71 \\
\hline 0.611 & 0.37 & 0.611 & 0.53 \\
\hline
\end{tabular}

Sectoral affiliation of the identified characteristics make a logical relationship between the level of technological change in the industry on a scale of X (enterprises in production, distribution and supply of energy resources) and technological capabilities of the region's enterprises on the scale of Y (the type of enterprises 1 - communal enterprise of heat supply, type of enterprises 2 - small enterprises that operate in some field of industry and services) (Figure 5, 6).

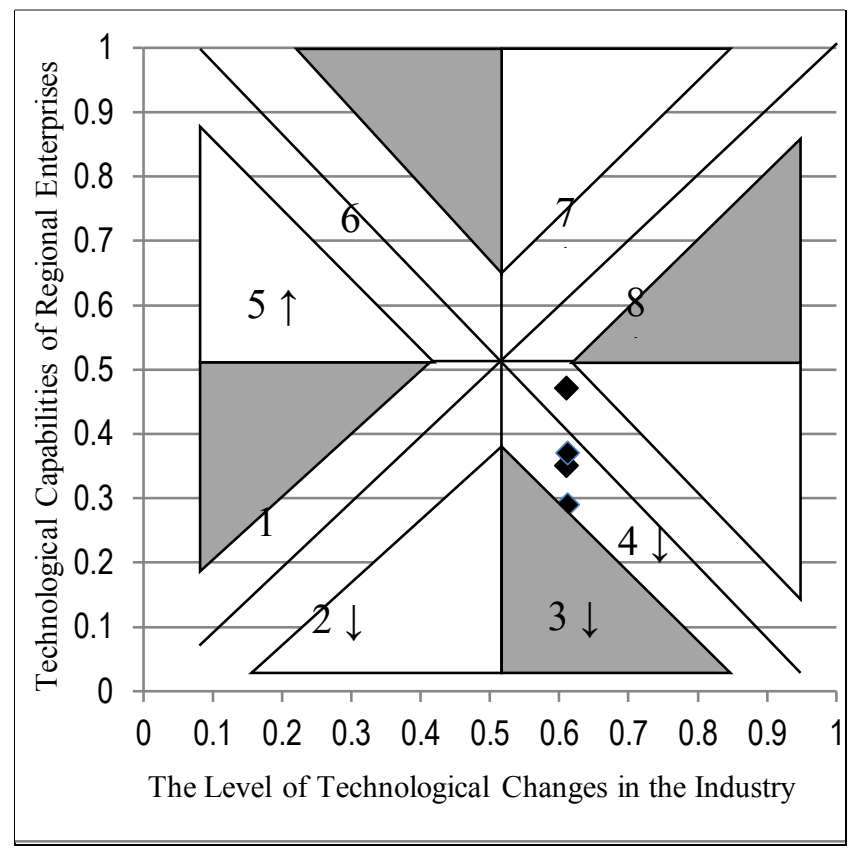

Fig. 5. Models of Competitive Environment of Enterprises in the Entrepreneurship Cluster - 1. 


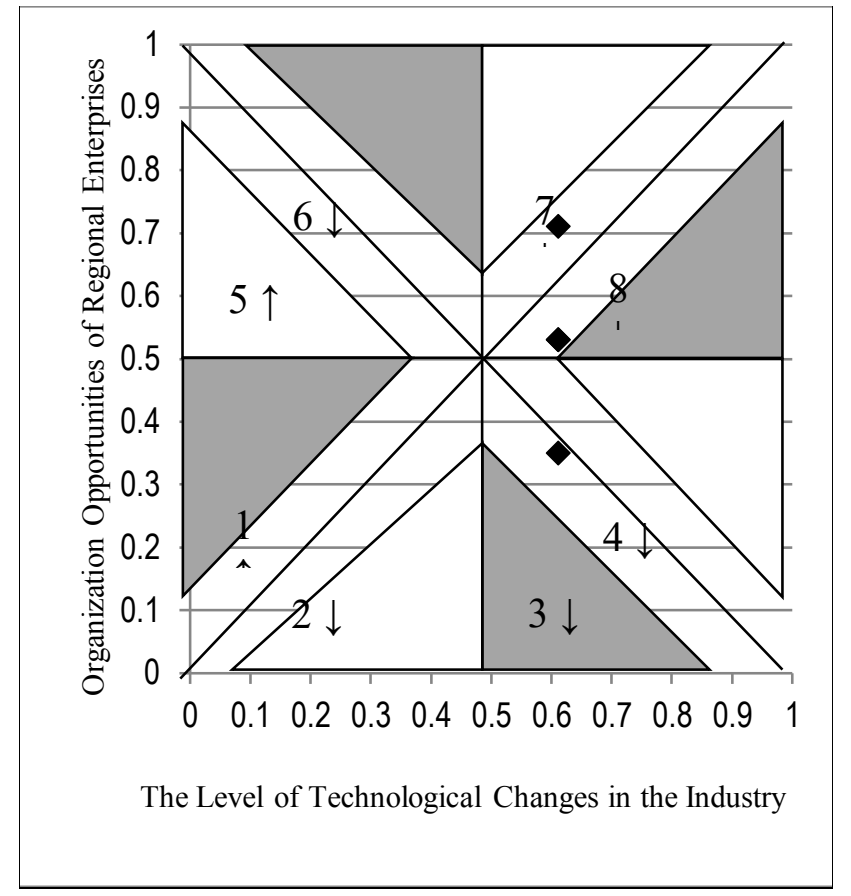

Fig. 6. Models of Competitive Environment of Enterprises in the Entrepreneurship Cluster - 2 .

\section{Conclusions and recommendations}

Spatial models of regional cooperation of industrial, communal and small enterprises in the entrepreneurship cluster confirm the feasibility of this form of economic activity. When small enterprises are successfully integrated with technological innovation in a cluster, the potential to design activities from sector 3 to sector 4 is released. In the case of the integration of small enterprises with organizational innovation in the cluster design reaches sectors 7 and 8 . This indicates the availability of innovative potential in the energy and service sectors and the possibility of its implementation through flexible forms of management.

There was defined the basic indicators of developmentof entrepreneurship cluster on the base of main components of the innovation potential and innovation performance of three groups of enterprises. It include: the industrial enterprises on production, distribution and supply of energy resources (integral rate of innovative component of economic development of the industrial enterprises on production, distribution and consumption of energy resources; communal enterprises providing services in heat supply (integral coefficient of its readiness to provide services in heat supply and to innovative transformations out of financial conditions); small enterprises which provide services in heat supply (integral index of functioning of small enterprises in the entrepreneurshipcluster). Based on this, there was graphically built models of competitive environment of enterprises that makethe entrepreneurshipcluster in the regional space. This approach indicatesabout the high role and efficiency of innovative transformation in the communal sector. 


\section{References}

1. P.V. Shukanov, Geography and Tourism 18, 192-198 (2012)

2. V.S. Bochko, Economics of the Region 1(41), 39-52 (2015)

3. I.I. Umansky, Bulletin of Khmelnitsky National University 2, 132-136 (2011)

4. V. Holodkova, A. Mottaeva, T. Pokrovskaya, E3S Web of Conferences 164, 11043 (2020) https://doi.org/10.1051/e3sconf /202016411043

5. V.P. Moskalenko, Mechanism of Economic Regulation 2, 109-120 (2009)

6. O.M. Tishchenko, Bulletin of National University «Lviv Polytechnic» 640, 406-415 (2008)

7. Yu.S. Shipulina, Mechanism of Economic Regulation 3, 58-63 (2008)

8. V.M. Vasilenko, Regional Economy 184 (2014)

9. A.A. Melikhov, Bulletin of Dnipropetrovsk University 8(3), 29-37 (2014)

10. L.S. Zakharkina, Strategic Planning in the System of Management of Innovative Development of Engineering Enterprises 12, 167 (2011)

11. S. Zahra, R. Sisodia, B. Matherne, European Management Journal 17(2), 188-203 (1999)

12. P.L. Chang, Y.C. Chen, Fuzzy Sets and Systems 63(2), 131-139 (1994) 